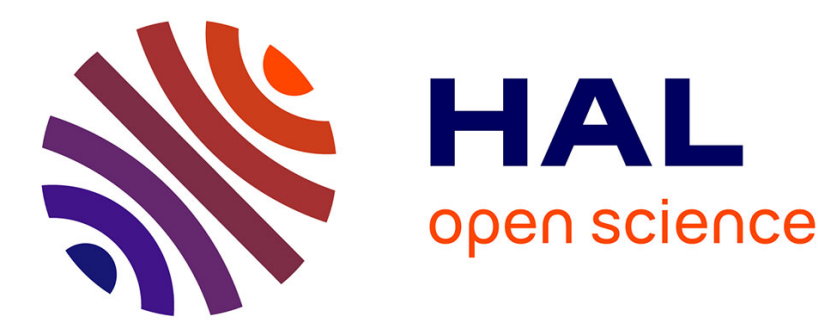

\title{
Introduction and Overview: the British and French Riots
}

\author{
Dave Waddington, Fabien Jobard, M. King
}

\section{To cite this version:}

Dave Waddington, Fabien Jobard, M. King. Introduction and Overview: the British and French Riots. Dave Waddington; Fabien Jobard; Mike King. Rioting in the UK and France. A Comparative Analysis, Willan Publishing, pp.3-12, 2009, 978-1-84392-504-0. hal-00550808

\section{HAL Id: hal-00550808 https://hal.science/hal-00550808}

Submitted on 22 May 2015

HAL is a multi-disciplinary open access archive for the deposit and dissemination of scientific research documents, whether they are published or not. The documents may come from teaching and research institutions in France or abroad, or from public or private research centers.
L'archive ouverte pluridisciplinaire HAL, est destinée au dépôt et à la diffusion de documents scientifiques de niveau recherche, publiés ou non, émanant des établissements d'enseignement et de recherche français ou étrangers, des laboratoires publics ou privés. 


\title{
Introduction and Overview : the British and French Riots
}

\author{
by David Waddington, Mike King and Fabien Jobard
}

\section{The French Riots and their Forerunners}

Academics and journalists have resorted to various forms of metaphor in attempting to characterise and explain the French riots of October to November 2005, which saw youths and police confronting one another nationwide against a seemingly constant backdrop of blazing cars and buildings. Some commentators alluded to natural or even supernatural phenomena in order to capture the essence of such drama. Schneider (2008), for example, likened the disorders to a 'maelstrom', while Wallerstein (2005) described them as exploding 'like a phoenix'. Others evoked unsettling comparisons with recent natural disasters describing the disorders as 'France's Hurricane Katrina' (Murray 2006) and a 'tsunami of inchoate youth rebellion' (Ireland 2005). Like countless other riots in history they were triggered off by a 'banal confrontation' (Brown 2007) on the afternoon of 27 October when police officers intercepted nine male youths thought to have been involved in the break-in of a shed on a housing estate in the Parisian town of Clichy-sous-Bois.

What transformed this innocuous affair into an incident of such international significance was the tragedy befalling a trio of the youths who had become unwittingly implicated in the encounter with the police. The three teenagers concerned (one of Turkish descent, the other two of African heritage) had been returning home from playing football in their school holidays when they were apprehended along with the other youths. Evidently fearing capture, or desperate at least to avoid the regular rigmarole of having their identity papers checked, the youths fled and took refuge in an electricity substation located to the rear of a nearby cemetery. This intensely dangerous environment quickly took its toll: the two Africans were fatally electrocuted, though the Turk somehow survived while still incurring extremely serious burns.

Rumours of this incident rapidly circulated the neighbourhood and, inside two hours, around 100 local youths embarked on a highly destructive 'rampage', setting fire to 23 vehicles in the process (Brown 2007). This action, and the two further nights of intermittent rioting that followed, occurred amidst a highly charged political atmosphere:

During the hours following the incident the Minister of Interior, Nicolas Sarkozy, accused the three youngsters of involvement in a burglary but denied that they had been chased. Three days earlier, visiting Argenteuil, another town of the banlieue, he had declared he would 'rid them of the racaille' (riff-raff), employing a term youths would use to insult each other. A few months before, commenting on the death of a child shot dead by a youth in the infamous Cité de 4000 in La Courneuve, Sarkozy had brutally announced that he would 'cleanse the neighbourhood with a Kärcher' (high-pressure hose).... Neither the government nor the police made any gesture of compassion or respect towards the grieving parents and relatives of the boys. (Fassin 2006: 1)

It seems probable that a widely reported secondary incident was responsible for spreading the conflagration. Reports emphasise that the rioting had actually been calming down by the night of 29/30 October following a silent march by 500 mourners and protesters, many of 
whom wore t-shirts proclaiming 'Dead for nothing' in honour of the two dead boys (Mucchielli 2008). However, on the evening of 30/31 October, police officers pursuing a group of local youths fired a tear gas grenade into a local mosque where worshippers were saying prayers for Ramadan. Scores of those present were asphyxiated but Mr Sarkozy denied that the police had been guilty of any wrongdoing (Schneider 2008). This incident and Sarkozy's denial had a catalytic effect, causing rioting to spread initially to other ZUSs (sensitive urban areas) in the 93rd Department of Seine-Saint-Denis. Its subsequent progress was inexorable. By 7 November, conflict had spread to well some 280 cities nationwide, causing the French Prime Minister to declare a state of emergency. The rioting continued with decreasing levels of intensity until 17 November, by which time it petered out.

The twenty-day period of disorder resulted in no further loss of life immediately linked to the collective violence - indeed, the only serious injuries sustained were those caused to a disabled woman who was severely burned when the bus she had boarded in Seine-SaintDenis was petrol-bombed by youths. There were few reports of looting, either. Nevertheless, the physical damage done was far from insignificant: a reported 201 police and 26 firefighters were injured in the riots, and as many as 10,000 private vehicles and 30,000 garbage cans were deliberately ignited. Further damage was done to 250 public buildings, raising the total cost of urban destruction to an estimated $€ 200$ million. The legal consequences of the rioting were equally far-reaching: 5,200 people were arrested, of whom 4,800 were placed in police custody and 600 subsequently imprisoned (Jobard 2008; Mucchielli 2008). Since the disorders of 2005, France has experienced further occasional instances of rioting, as in the Parisian banlieue of Villiers-le-Bel in November 2007, Grigny in May 2007, and little-known small towns, such as Saint-Dizier (in October 2007) and Vitry-le-François and Romans-surIsère (in June and October 2008, respectively).

Though certainly unprecedented in scope and duration, the French riots are a far from novel phenomenon. In the quarter of a decade predating the 2005 riots, French society was affected by a catalogue of major urban disorders (e.g. Bonelli 2007; Oberti, 2008). Zauberman and Levy (2003: 1073) note how, even by the late 1990s, a particular pattern had emerged:

These incidents may result from police shootings - whether lawful, unlawful or accidental. More often, they result from lethal traffic accidents occurring during a police chase of youth trying to escape an arrest in a stolen vehicle. Riots are also triggered by the outcomes of judicial investigations or trials, when local youth feel that the police officers involved have been unjustly cleared or too leniently sentenced.

It is evident that the incident that first triggered the 2005 riots was entirely consistent with this recent French tradition.

\section{Making Sense of the Riots}

During the 2005 riot period and in its aftermath, numereous possible explanations were put forward for the violence and destruction. Some political and media pundits argued that the disorders had been deliberately provoked by 'Islamic fundamentalist extremists', were the consequence of provocative hip-hop lyrics, or were a by-product either of the dysfunctionally polygamus Muslim families or inherent criminality of the 'riff-raff' inhabiting the French banlieues (Laachir 2007; Mucchielli 2008; Waddington 2008). The view that the allegedly 'contagious' dispersal of the riots was due to the 'copycat' effect of television coverage also gained widespread political currency (Waddington op. cit.). 
Oppositely, it was generally asserted that the riots (émutes) constituted a nationwide révolte (or 'rebellion') by the socially disaffected youth residents of the banlieues. There was little here to distinguish the views of such diverse organs as the pro-Sarkozy French weekly newspaper, Le Journal du Dimanche, whose editorial of 6 November 2005 spoke of 'forgotten generations' of geographically concentrated youths telling of their 'hatred' and 'despair' towards French society, and the left-leaning British daily, The Guardian, whose feature writer, Jonathan Freedland, expressed the opinion that:

The riots themselves are not hard to fathom; several French commentators have said the only mystery is why they didn't break out 15 years earlier. If you corral hundreds of thousands of the poor and disadvantaged into sink estates and suburbs in a misery doughnut around the city, expose them to unemployment rates of up to $40 \%$, and then subject them to daily racial discrimination at the hands of employers and the police, you can hardly expect peace and tranquillity. Cut public spending on social programmes by $20 \%$ and you will guarantee an explosion. All you have to do is light the fuse. (9 November 2005)

Political and media debate also focused in part on the relative merits of the British and French approaches to incorporating ethnic diversity (Guardian 12 November 2005). The British model of multiculturalism is supposed to encourage diverse communities to develop semiautonomously while preserving their own, unique identities; the corresponding French assimilatory model demands, as its name suggests, the incorporation of its migrant populations into a French way of life in which everyone is accepted as 'equal and the same' as soon as French citizenship and nationality has been conferred upon them (Favell 1998, Garbaye 2005; Weil and Crowley, 1994).

Murray (2006: 37) points out that the French and British appear to harbour a mutual disdain for each other's primary model of society. He maintains how the French are apt to perceive the British model as a 'multitude of ethnic and religious ghettos'. In the wake of the London bombings of July 2005, French newspapers like Le Monde asserted that it was due to the robustness of the French model that there had been no such terrorist attacks in France (Laachir 2007: 50). British commentators reacted just as censoriously to the events of November 2005. For instance, the Chair of the British Commission for Racial Equality (CRE) graphically asserted how: 'The hundreds of cars that have now been burnt in French streets are pyres that mark the passing of a French delusion - that the incantation of 'liberté, égalité, fraternité' would somehow mask the réalité of life for non-white French men and women: repression, discrimination, segregation' (Observer 6 November 2005).

What is certainly evident, even from this brief review, is that more systematic and considered sociological analysis is required of such matters as: the social profiles of the rioters and the precise nature of their grievances; the background conditions against which the riots occurred; the manner in which they broke out and spread across the 300 towns that were eventually involved; the possible roles in all this of authoritative institutions like the police and media; and the possible importance of race and ethnicity. It is on these and related issues that contributors to this book will be focusing their attention.

\section{The British Riots, 1980-2005}

British observers of the French riots already had the benefit of a 35-year experience of recent rioting in their own country on which to formulate their ideas. In the early and mid-1980s, there were recurring confrontations in crumbling UK inner-city areas involving police and, predominantly, African-Caribbean youths. First to appear was the $1980 \mathrm{St}$ Paul's (Bristol) 
riot where, 'Greatly outnumbered and unprepared for the anger of the community, the police were forced to withdraw, after attempting to confront the youth with military-style tactics for two hours. For four hours while the police awaited reinforcements, St Paul's was a "no-go" area' (Muncie 1984: 85). Though initially dismissed as a 'social aberration, the Bristol riot was actually a portent of the more widespread rioting occurring one year later in major innercity areas like Brixton (London), Moss Side (Manchester), Handsworth (Birmingham), Toxteth (Liverpool) and Chapeltown (Leeds). The earliest and most serious of these was the Brixton riot of 10-12 April 1981 which saw black youths overturning cars and using petrol bombs against the police. Twenty-eight buildings were set alight and a total of 279 police officers reported injured (Lea 2004).

In 1991 and again in 1992, it was the turn of white working-class youths on the run-down and heavily stigmatised council housing estates of places like Cardiff, Oxford, Coventry and Newcastle to run riot in their localities. Such disorders constituted 'street battles' between youth and local police officers intervening in response to various forms of 'car crime', such as 'hotting' (performing acrobatic stunt driving on local streets) or 'joyriding' stolen cars (Campbell 1993; Lea 2004; Power and Tunstall 1997). There were four confrontations of this nature in 1991 and a further nine one year later.

Closest in similarity to the French disorders were the riots occurring in a handful of former mill towns and cities in West Yorkshire and East Lancashire in the spring and early summer of 2001. Following a minor disturbance in Bradford (West Yorkshire) on 14-15 April, more serious disorders occurred in Oldham (Greater Manchester), Burnley (Lancashire) and then in Bradford once again. The central participants in each of these riots were the police and British-born youths of Pakistani and Bangladeshi origin. In all cases the disorder broke out in close proximity to areas chiefly occupied by Asian Muslims, following the trouble causing activities of white racists (Kalra 2002). To briefly summarise,

\footnotetext{
In Oldham on 26-29 May around 500 people were involved, injuring 2 police officers and 3 members of the public with damage estimated at $£ 1.4$ million. In Burnley about 400 were involved on $24-26$ June, with 83 police officers and 28 members of the public injured, and damage estimated at over $£ 0.5$ million. Finally, in Bradford up to 500 people were involved in 'riots' over the weekend of 7-9 July. The injured included 326 police officers and 14 members of the public with estimates of damage to property ranging up to $£ 10$ million...Around 400 people have been arrested in relation to the disturbances in Bradford, Burnley and Oldham. (Bagguley and Hussain 2003: 1)
}

The Oldham riot occurred when, following an argument between a 36-year-old white woman and pair off Asian youths, members of a white racist organisation (Combat 18) carried out retributive attacks on nearby Asian residents and their properties. Thereafter, a more serious and prolonged confrontation developed between the police and Asian young men who accused the former, not only of failing to adequately respond to the fascist attacks, but of actually providing protection to the white assailants (Waddington 2007).

A more complicated series of events in Burnley began with a late-night assault on an Asian taxi driver - answered later the following day by a retaliatory attack involving 70 Asian men on a public house frequented by members of the Far Right. Hostilities resumed on the following day when Asian youths fought with police officers struggling to separate them from white racists staging an impromptu march within the boundaries of an Asian residential area (King and Waddington 2004). 
Finally, the Bradford riot occurred in the context of an anti-fascist rally called in response to rumours of an impending appearance in the city centre by members of the Far Right British National Party (BNP). Heightened tension apparently resulting from a series of minor altercations and abusive behaviour involving BNP activists developed into a confrontation between police and demonstrators. Such conflict was exacerbated following a police strategy of pushing Asian participants away from the city centre towards the Asian-dominated residential area of Manningham (Hussain and Bagguley 2005).

A succession of official reports soon appeared, with each one setting out the possible causes of the riots and making associated policy recommendations (Cantle 2001; Clarke 2002; Denham 2002; Ritchie 2001). These tended to highlight the significance of such factors as the 'self exclusion' of Asian Muslims from British society, the absence of credible political leadership within their ranks, and the growing criminality of Asian youth. Corresponding academic research and analysis shifted the focus of discussion onto such issues as social disadvantage and deprivation, political marginalisation and disaffection, youth alienation and deviance, and the possible contributing roles of the police and media (e.g. Amin 2002; Kalra 2002; Kundnani 2001; Lea 2004). Such debates were given further impetus and significance following rioting (on 22-23 October 2005) in the Lozells area of Birmingham, where clashes between Asian and African-Caribbean youths were precipitated by a rumour that a 14-yearold African girl had been 'gang raped' by a youths of Asian heritage (Guardian 29 November, 2005).

\section{The Origins and Focus of the Book}

It soon became apparent to the editors of this volume that British attempts to analyse and remedy the underlying causes of the 2001 riots might constitute a potentially valuable resource to French academics, practitioners and policy makers currently striving to make sense of and formulate reactions to the recent disorders. We likewise considered that the French experience could provide a fertile basis for re-applying, testing and enhancing existing British theory and policy. Hence, we successfully applied to the British Economic and Social Research Council (ESRC) and French Agence nationale de la recherche (ANR) to undertake a series of exploratory workshops, geared to exchanging information, developing theory and formulating recommendations for just and sensible social policy.

The core (permanent) group of participants in these workshops comprised eight British and eight French academics with interests in the UK and/or French riots. Included in this group were one British and two French doctoral students. The British participants were drawn from a range of separate disciplines, encompassing communication studies, criminology, peace studies, youth work, sociology and urban regeneration. French colleagues exhibited similar diversity, coming from such disciplines as criminology, police studies, politics, sociology and urban studies. In addition to this permanent group, the workshops incorporated an equally diverse collection of one-off ('occasional') guest speakers, both academics and practitioners (ranging from police personnel to community workers and housing officers).

Following a preliminary planning meeting of the grant holders in Paris in December 2006, a series of three 2-day workshops took place in 2007. These were held in Sheffield (on 14-16 February), Paris (17-19 June) and Birmingham (24-26 October). The first workshop was primarily concerned with the description and analysis of the English riots of April to July 2001. The second workshop placed corresponding descriptive and analytical emphasis on the 
French riots of October-November 2005. The final workshop paid particular attention to policy initiatives implemented in the wake of the British disorders. Part of this final session was also devoted to ensuring the widest possible dissemination of our conclusions and policy recommendations. It was with this objective in mind that the idea of creating this volume was conceived and has since achieved fruition.

\section{The Book's Contents and Scope}

The book is presented in four parts. Part 1 comprises our attempt to 'set the scene' by placing the British riots of 2001 and French riots of 2005 and after in their appropriate historical and theoretical contexts. Thus, in Chapter 2, David Waddington and Mike King provide an overview of the British disorders of the 1980s and 1990s, and of attempted academic explanations. Chapter 3 constitutes a corresponding overview by Fabien Jobard of the French riots of 1981-2004. The purpose of these preliminary chapters is to outline theoretical constructs and insights that are potentially capable of informing our analyses of the most recent riots in each country.

The five chapters comprising Part II of the book focus primarily on the British riots of 2001 and 2005. In the first of these (Chapter 4), Virinder Kalra and Chris Rhodes identify the significance of the 'local histories' underpinning the 'identity politics' of the riot affected areas of Oldham and Burnley. They argue that conflict in these towns was facilitated and encouraged by such crucial 'technologies of information flow' as the manipulation of the local media and Internet, and the 'calling to arms' of riot participants via taxi radio networks and use of the mobile phone.

Janet Bujra and Jenny Pearce's analysis of the police's experience of the Bradford riot (Chapter 5) highlights the subjective and operational tensions involved in the management of inter-ethnic conflict. A corresponding analysis by Paul Bagguley and Yasmin Hussain in Chapter 6 of civilian participation in the Bradford riot emphasises not only the wide variation of underlying motives for engaging in disorder, but also the extent to which individual orientations towards the police and violence were anything but constant or consistent.

There is a shift of focus in Chapter 7, in which Paul Thomas uses a case study of youth work in Oldham to test out the implications of the UK Government's post-riot policy emphasis on 'Community Cohesion'. Sceptics of such policy had made dire predictions of it leading to the 'death of multiculturalism' but Thomas suggests that its accent on prejudice reduction and relationship building has enabled ethnic diversity to flourish. Mike King's equally singular discussion (in Chapter 8) traces the background to and genesis of the 2005 riot in the Lozells district of Birmingham which was unusual for the involvement of rival factions of Asians and African-Caribbeans.

The change of emphasis in Part III onto the French riots of 2005-8 begins with Hugues Lagrange's discussion, in Chapter 8, of some of the key structural variables (e.g. employment, housing, population segregation, employment, ethnicity and family size) underlying riot propensity. One of these themes - exploring the relationship between rioting and the recent instigation of particular French housing and urban regeneration programmes - is taken up by Renaud Epstein in Chapter 10. This is followed by Camille Hamidi's discussion, in Chapter 11 , of the possible influence on the rioting of the historically poor political representation of migrant workers in French society. 
The next three chapters represent counterparts to our earlier Chapters 5 and 6 . Thus, in Chapter 12, Michel Kokoreff explores the experiences and political belief systems of those youths who participated or, conversely, refrained from engaging, in the riots. Following this, Marwan Mohammed outlines (in Chapter 13) his in-depth field study of youth gangs from one particular cite involved in the 2005 riots. Specific emphasis is placed on the relationships existing between the youths and local politicians, and of the routine role of violence in everyday political affairs. Christian Mouhanna then speculates (in Chapter 14) in terms of those characteristics of the French policing system which helped to give rise to eventual confrontation. The final chapter of this Part, by Christine Fauvelle-Aymar, Abel François and Patricia Vornetti, then considers the impact of the French riots in terms of their possible influence on voting patterns and other forms of political behaviour.

In Part IV we briefly divert our attention onto rioting (or the absence of such conduct) in other major western societies. In Chapter 16, David Waddington investigates the possible causes of the only major instance of rioting to occur in the United States of America in the new Millennium by focusing on the 2001 Cincinnati riot and subsequent attempts by local actors to avoid a repetition. Tim Lukas then concentrates (in Chapter 17) on those aspects of German police policy towards ethnic minorities which, he considers to have been instrumental in ensuring an absence of rioting in that nation.

The final chapter of the book draws both the lessons to be learned from these earlier contributions and insights from the wider literature into a comparative discussion of the main causes of the rioting in the United Kingdom and France. Such discussion is then used as a springboard for evaluating current social measures and recommending future policy initiatives.

\section{References}

Bagguley, P. and Hussain, Y. (2003) 'The Bradford riot of 2001: a preliminary analysis'. Paper presented to the Ninth Alternative Futures and Popular Protest Conference,, Manchester Metropolitan University, 22-24 April 2003.

Bonelli, L. (2007) 'Policing the youth: towards a redefinition of discipline and social control in French working-class neighbourhoods', in S. Venkatesh \& R. Kassimir (Eds.) Youth, Globalization and the Law. Palo Alto, CA.: Stanford University Press: 90-123.

Brown, (2007) Brown, B.E. (2007) 'God and man in the French riots', American Foreign Policy Interests, 29: 183-199.

Campbell, B. (1993) Goliath: Britain's Dangerous Places. London: Methuen.

Cantle, T. (2001) Community Cohesion: A Report of the Independent Review Team. London: The Home Office.

Clarke, Lord T. (2001) The Burnley Task Force Report. Burnley: Burnley Borough Council.

Denham, J. (2002) Building Cohesive Communities: A Report of the Mnisterial Group on Public Order and Community Cohesion. London: The Home Office. 
Fassin, D. (2006) 'Riots in France and silent anthropologists', Anthropology Today, 22(1): 13.

Favell, A. (1998) Philosophies of Integration: Immigration and the Idea of Citizenship in France and Britain. Palgrave: Macmillan.

Garbaye, R. (2005) Getting Into Local Power: The Politics of Ethnic Minorities in British and French Cities. Oxford: Blackwell Publishing.

Hussain, Y. and Bagguley, P. (2005) 'Citizenship, ethnicity and identity: British Pakistanis after the 2001 "riots"', Sociology, 39(3): 407-425.

Ireland, D. (2005) 'Why is France burning? The rebellion of a lost generation', Axis of Logic, 9 November 2005. http://www.axisoflogic.com/artman/publish/article_19897.shtml.

Jobard, F. (2008) 'The 2005 French Urban Unrests: Data-Based Interpretations', Sociology Compass, 2(4): 1287-1302

Kalra, V.S. (2002) 'Riots, race and reports: Denham, Cantle, Oldham and Burnley Inquiries', Sage Race Relations Abstracts, 27(4): 20-30.

Kalra, V.S. (2003) 'Police lore and community disorder: diversity in the criminal justice system', in D. Masoon (ed.) Explaining Ethnic Differences: Changing Patterns of Disadvantage in Britain. Bristol: The Policy Press.

King, M. and Waddington, D. (2004) 'Coping with disorder? the changing relationship between police public order strategy and practice - a a critical analysis of the Burnley riot', Policing and Society, 14 (2): 118-137.

Laachir, K. (2007) 'France's "ethnic" minorities and the question of exclusion', Mediterranean Politics, 12(1): 99-105.

Lea, J. (2004) 'From Brixton to Bradford: Ideology and discourse on race and urban violence in the United Kingdom', in G. Gilligan and J. Pratt (eds) Crime, Truth and Justice: Official Inquiry, Discourse, Knowledge. Cullompten: Willan.

Mucchielli (2008) 'Fall 2005: a review of the most important riots in the history of French contemporary society', Journal of Ethnic and Migration Studies, forthcoming.

Muncie, J. (1984) The Trouble With Kids Today. London: Hutchinson.

Murray, G. (2006) 'France: the riots and the republic', Race and Class, 47(4): 26-45.

Oberti, M., (2008) 'Urban riots in France', EuroTopics. Available at:

http://www.eurotopics.net/en/magazin/magazin_aktuell/frankreich-2008-07/oberti/ .

Power, A. and Tunstall, R. (1997) Dangerous Disorder: Riots and Violent Disturbances in Thirteen Areas of Britain, 1991-92. York: York Publishing Services/Joseph Rowntree Foundation. 
Ritchie, D. (2001) Oldham Independent Review Panel Report. Oldham: Oldham Metropolitan Borough Council and Greater Manchester Police.

Schneider, C.L. (2008) 'Police power and race riots in Paris', Politics and Society, 36(1): 133-159.

Waddington, D. (2007) Policing Public disorder: Theory and Practice. Cullompton: Willan.

Waddington, D. (2008) 'The madness of the mob? Explaining the "irrationality" and destructiveness of crowd violence', Sociology Compass, 2(2): 675-87.

Wallerstein, (2005) 'The French riots: rebellion of the underclass', Commentary, 174, 1 December 2005.

http://www.binghamton.edu/fbc/174en.htm

Weil, P. and Crowley, J. (1994) 'Integration in theory and practice: A comparison of France and Britain', West European Politics, 17(2): 110-126.

Zauberman, R. and Levy, R. (2003) 'Police, minorities, and the French republican ideal', Criminology, 41(4): 1065-1100. 